Bulletin UASVM Food Science and Technology 70(1)/2013, 60-61

ISSN-L 2344-2344; Print ISSN 2344-2344; Electronic ISSN 2344-5300

\title{
Assessment of Physicochemical and Microbiological Quality of Seafood
}

\section{Sorin APOSTU, Ancuta M. ROTAR, Cristina Anamaria SEMENIUC, Carmen POP}

University of Agricultural Sciences and Veterinary Medicine Cluj-Napoca, Address - 400372 - ClujNapoca, Mănăştur Street, number 3-5, România; soriapostu@ yahoo.com

\begin{abstract}
The aim of this work is to evaluate the physicochemical and microbiological attributes over a period of 5 months for two products from the category of Seafood: calamari rings and seafood cocktail. Appreciation of the freshness of seafood was tested by determining $\mathrm{pH}$, easily hydrolysable nitrogen, the reaction Eber / Nessler and reaction with hydrogen sulphide according to SR ISO 2917:2007, SR 90657:2007 and SR 9065-7:2008. The results of microbiological determinations for batch 1 revealed an increase in the number of sulphite-reducing clostridia than the maximum limit. Results obtained from physico-chemical determinations were within the maximum permissible by data legislation. The food quality is influenced by non-hygienic conditions of storage, handling and marketing.
\end{abstract}

Keywords: calamari rings, seafood cocktail, food quality

Introduction. Seafood products are appreciated worldwide for their high nutritional value and are increasingly popular among consumers, although Carlos Cardoso et al. (2013) argue that the concerning seafood consumption preferences, the universe of respondents clearly prefer wild to farmed fish, $62.9 \%$ vs. $29.3 \%$. Consumer preferences range from fresh products, eaten raw or minimally processed, to variously prepared (salted, smoked, cured, canned) and ready-to-eat (RTE) products. Moreover, seafood products are a major food category in international trade and are frequently shipped very long distances, where occurs the variety of contaminations (Amagliani et al., 2012).

Aims. The main problem of valorification and marketing of the marine animal meat is to maintain its quality, given its low conservabiliy. The purpose of this work is to evaluate the physicochemical and microbiological attributes over a period of 5 months (storage and marketing) for two products in category Seafood: calamari rings and seafood cocktail.

Materials and methods. Samples were collected from four different batches, frozen, as a form of commercialization. The microbiological risks were assessed by determining total mesophilic aerobic bacteria, coliform bacteria, the presence of Salmonella, Staphylococcus aureus, the incidence of Escherichia coli and Clostridium perfringens. Appreciation of the freshness of seafood was tested by determining $\mathrm{pH}$, easily hydrolysable nitrogen, the reaction Eber/Nessler and reaction with hydrogen sulphide according by SR ISO 2917:2007, SR 90657:2007 and SR 9065-7:2008.

Results. The results of microbiological determinations for batch 1 revealed an increase in the number of sulphite-reducing clostridia than the maximum limit and the results of $\mathrm{pH}, \mathrm{H}_{2} \mathrm{~S}$, Easily Hydrolysable Nitrogen, Eber Reaction and Nessler Reaction for the samples analyzed were within the maximum permissible by data legislation. 
Tab. 1

The results of microbiological analyzes of samples taken from three different supermarkets

\begin{tabular}{lcccccc}
\hline Samples & $\begin{array}{c}\text { Total mesophilic } \\
\text { aerobic bacteria/g }\end{array}$ & $\begin{array}{c}\text { Coliform } \\
\text { bacteria/g }\end{array}$ & $\begin{array}{c}\text { Salmonella/25 } \\
g\end{array}$ & $\begin{array}{c}\text { E. } \\
\text { coli/g }\end{array}$ & $\begin{array}{c}\text { Coagulase_Positive } \\
\text { Staphylococci/g }\end{array}$ & $\begin{array}{c}\text { Sulphite- } \\
\text { reducing } \\
\text { clostridia }\end{array}$ \\
\hline $\begin{array}{l}\text { Calamari } \\
\text { ringsM }\end{array}$ & 12000 & 0 & $\mathrm{Abs}$ & $\mathrm{Abs}$ & $\mathrm{Abs}$ & $\mathrm{Abs}$ \\
$\begin{array}{l}\text { Seafood } \\
\text { cocktailM }\end{array}$ & 16000 & 1,6 & $\mathrm{Abs}$ & $\mathrm{Abs}$ & $\mathrm{Abs}$ & 8 \\
$\begin{array}{l}\text { Calamari } \\
\text { ringsB }\end{array}$ & 10000 & 0 & $\mathrm{Abs}$ & $\mathrm{Abs}$ & $\mathrm{Abs}$ & $\mathrm{Abs}$ \\
$\begin{array}{l}\text { Seafood } \\
\text { cocktailB }\end{array}$ & 18000 & 0 & $\mathrm{Abs}$ & $\mathrm{Abs}$ & $\mathrm{Abs}$ & $\mathrm{Abs}$ \\
$\begin{array}{l}\text { Calamari } \\
\text { ringsS }\end{array}$ & 16000 & 0 & $\mathrm{Abs}$ & $\mathrm{Abs}$ & $\mathrm{Abs}$ & $\mathrm{Abs}$ \\
$\begin{array}{l}\text { Seafood } \\
\text { cocktailS }\end{array}$ & 14000 & 0 & $\mathrm{Abs}$ & $\mathrm{Abs}$ & $\mathrm{Abs}$ & $\mathrm{Abs}$ \\
\hline
\end{tabular}

Note: M, B, S - Three supermarkets

By not respecting the storage conditions of the products, due to the temperature fluctuations were observed the increases of the number of microorganisms analyzed.

\section{Conclusion}

The food quality is influenced by non hygienic conditions of storage, handling and marketing. Every processor is required to use an HACCP-based system, able of identifying sources and points of process, to decrease these risks thru monitoring.

\section{REFERENCES}

1. Carlos Cardoso, Helena Lourenço, Sara Costa, Susana Gonçalves, Maria Leonor Nunes (2013). Survey into the seafood consumption preferences and patterns in the Portuguese population, Appetite, Volume 64, Pages 20-31.

2. G. Amagliani, G. Brandi, G.F. Schiavano (2012). Review - Incidence and role of Salmonella in seafood safety. Food Research International 45 780-788. 